\title{
Efficiency of suspended solid removal from tofu production using Rotating Biological Contractor (RBC)
}

\author{
Shafira Septriani ${ }^{1}$, Norman Arie Prayogo ${ }^{2}$, Asrul Sahri ${ }^{2}$,Christopher L. Brown ${ }^{1 *}$ \\ ${ }^{1}$ Division of Fisheries Science, The Graduate School of World Fisheries University, Pukyong \\ National University, Busan, Republic of Korea \\ ${ }^{2}$ Department of Aquatic Resources Management, Faculty of Fisheries and Marine Science, Jenderal \\ Soedirman University, Purwokerto, Indonesia
}

\begin{abstract}
Tofu is a common food in Indonesia, made from soybean, and needs gigantic water for the process. The liquid waste of the tofu industry is usually directly discharged into the river without being processed. Liquid wastes of tofu have high organic content and become a problem in water pollution. Rotating Biological Contactor (RBC) is efficient method to treat waste with a high organic matter load by utilizing microorganisms to consume organic matter through biofilms. Biofilm will degrade organic matter aerobically. The purpose of the study is to determine the capability of $\mathrm{RBC}$ to reduce the organic content of tofu wastewater with different rotations of the disk. Rotation was experimentally varied from $30,40,50$, $60 \mathrm{RPM}$ and control. Results were considered in percentage decrease from the untreated waste: TSS of $87.56 \pm 6.48 \%$, BOD of $99.13 \pm 0.21 \%$, and COD of $98.53 \pm 0.08 \%$. To conclude, the optimum rotation is 50 RPM for decreasing BOD and COD, otherwise 40 RPM for reducing TSS. The results effluent $\mathrm{RBC}$ on three parameters passed the quality standards legally for the soybean processing company or activity.
\end{abstract}

\section{Introduction}

Tofu is one of the staple foods for Indonesian. In general, tofu is made from soybean as the raw material. The home industry has challenges in handling liquid waste. Each kilogram of tofu takes 45 liters of water and produces 43.5 liters of wastewater. Home industries in Banyumas, Central Java, were producing $40.000 \mathrm{~L}$ wastewater per day. The liquid waste is usually directly discharged into the river without process. Tofu waste contains high organic matter and indicates by the high values of Biological Oxygen Demand (BOD) and Chemical Oxygen Demand (COD) as the parameters [4].

It is [7] reported, tofu waste contained BOD approximately $6000-8000 \mathrm{mg} / \mathrm{L}, \mathrm{COD}$ approximately 7500-14000 mg/L, Total Suspended Solid (TSS) 638-660 mg/L, turbidity 524-585 FTU, and pH 4-6. Tofu waste has negative impacts on reducing the quality of the environment, physically, chemically, and biologically [3]. Several biological impacts of

\footnotetext{
* Corresponding author: brownchristopher38@gmail.com
} 
tofu waste on aquatic organisms' life are the rapid growth of parasites and harmful bacteria and disrupting the process of respiration and eutrophication [9, 12].

There are many methods of wastewater treatment generally: including physical, chemical, and biological. Biological treatment aims to reduce or eliminate the content of organic matter in the waste by microorganisms into other substances that are more stable. One of the biological treatments is Rotating Biological Contactors (RBC). RBC in the form of a practically horizontal tank, in which there are several discs arranged in parallel with close distances. Biofilm establishes and grows attached to the surface of the disc. The disc will rotate at a certain speed and contact the air after it comes into contact with wastewater [8].

The application of the RBC system has been widely carried out to treat waste from large-scale industries. Otherwise, using RBC for small-scale industries is infrequent even though the number of small-scale industries is considerably more than large industries. Research on variations in rotation with a maximum speed of 60 RPM and modification of $\mathrm{RBC}$ media discs has not ever been done to determine the level of effectiveness of RBC.

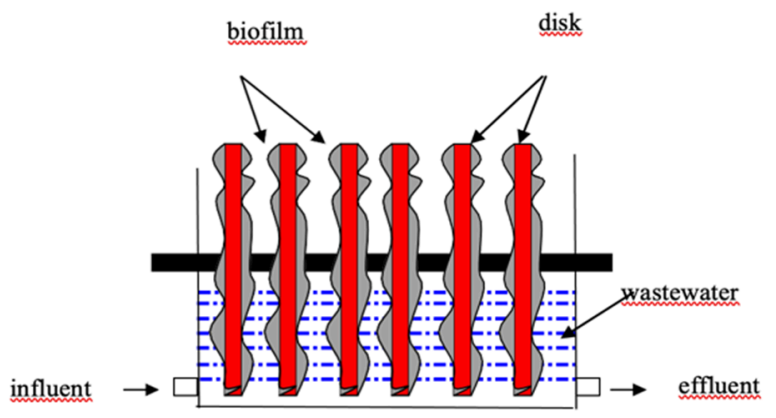

Fig. 1. RBC system is be equipped with a sedimentation tank unit that has disks (membrane) arranged in parallel as a host of microorganisms for degrading suspended solid. The RBC membranes are immersed in a 60 percent volume of level wastewater, with two holes as inlet influent and outlet effluent [6]

\section{Material and Methods}

\subsection{Experiment Set-Up}

This research was conducted by an experimental method using Completely Randomized sampling. The treatment consists of four sequence rotations, starting from 30, 40, 50, 60 RPM and control (0) without discs. The numbers of samples are four replicates to each tank. Different rotation treatments were carried out for two days operation and continued to samples analyze [13]. Major parameters are TSS, BOD, and COD.

\subsection{RBC Construction}

The RBC tank construction in this study was made from an iron plate frame form in a tank with a length and width of $30 \mathrm{~cm}$ and a height of $20 \mathrm{~cm}$. The media is made of discs with a diameter of $12 \mathrm{~cm}$ and is covered with carpet as a medium for attaching of biofilm layer. The numbers of discs in one tank are 22 pieces and divided into two sets. The volume of every tank is 7 liters, with an inlet and outlet (see Figure 1). 
A

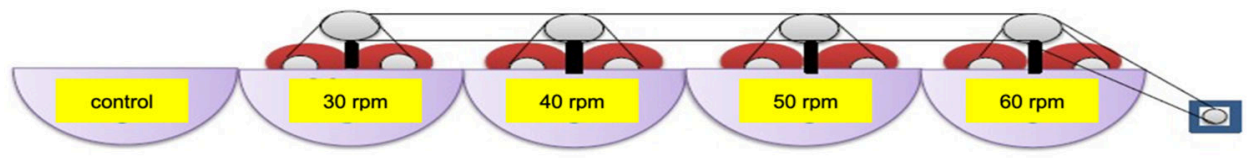

B

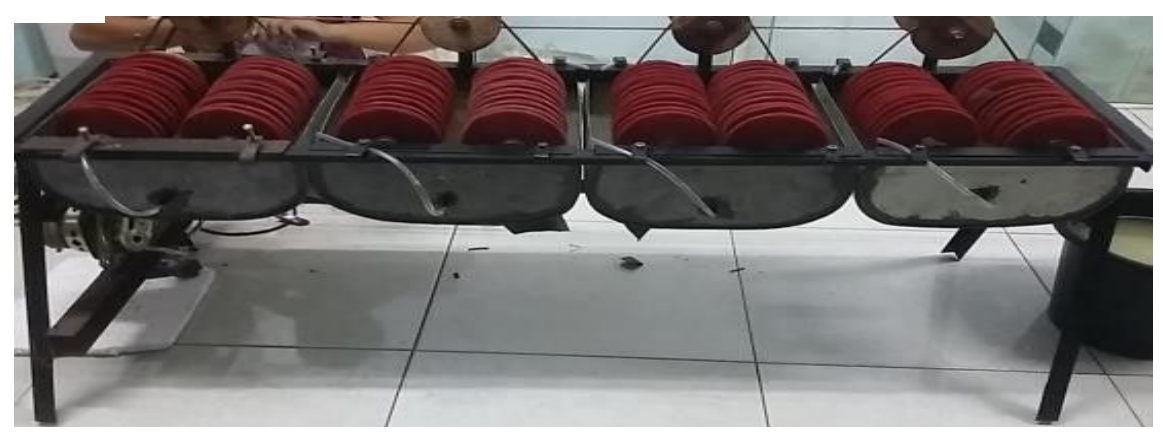

Fig. 2. (A) Schematic layout of the lab-scale RBC unit with four sequence rotations $(30,40,50,60$ RPM respectively). The four tanks are pulled by one pulley that is connected to the same dynamo. $\mathrm{RBC}$ system has two dynamos which will automatically change every 1 hour to avoid overheating. One other tank is considered as a control without any RBC treatment. (B) Real RBC prototype.

\subsection{Data Analysis}

\subsubsection{Efficiency (E)}

Efficiency is determining the percentage of removal of the suspended solid content of tofu industrial wastewater, including TSS, BOD, and COD, with the following equation.

$$
E=\frac{S o}{S e} \times 100 \%
$$

$\mathrm{E} \quad=$ Efficiency $(\%)$

So $\quad=$ Start Suspended Solid Value $(\mathrm{mg} / \mathrm{L})$

$\mathrm{Se} \quad=$ Final Suspended Solid Value $(\mathrm{mg} / \mathrm{L})$

\subsubsection{Statistical Analysis}

Data analysis was carried out to determine the reactions to the differential rotation. The results were then statistically analyzed to compare the significance of apparent differences between treatments. All statistical tests were done using Graph Pad Prisma, version 9. First, the data were checked with f-test, followed ANOVA, and expressed with mean $\square$ SEM data of each and between the time-groups. Further analysis of data was carried out using a Tukey's test $(\mathrm{p}<0.05)$. The mean values ( $\mathrm{p}$-value) indicated by different superscripts were significantly different. One superscript indicates a relatively weak but significant difference ( $\mathrm{p}$-value $<0.05$ ), two superscripts indicate a medium difference ( $\mathrm{p}$-value $<0.005$ ), and three superscripts indicate a strongly significant difference $(\mathrm{p}$-value $<0.001)$. 


\subsubsection{Comparative Descriptive Analysis}

Compared organic matter content of tofu industrial wastewater with quality standards of wastewater quality according to Indonesian law.

Table 1. Industrial Waste Quality Standards According to the Decree of the Minister of Environment No. $5 / 2014$

\begin{tabular}{|c|l|c|c|}
\hline No. & \multicolumn{1}{|c|}{ Parameter } & Unit & Maximum Rate \\
\hline 1. & Total Suspended Solid (TSS) & $\mathrm{mg} / \mathrm{L}$ & 200 \\
\hline 2. & Biological Oxygen Demand (BOD) & $\mathrm{mg} / \mathrm{L}$ & 150 \\
\hline 3. & Chemical Oxygen Demand (COD) & $\mathrm{mg} / \mathrm{L}$ & 300 \\
\hline
\end{tabular}

\section{Results}

The principle of wastewater treatment with $\mathrm{RBC}$ is wastewater containing organic pollutants and contact with a layer of microorganisms (microbial film) attached to the media's surface in a reactor. Biofilm is a structured bacterial community with a certain thickness, used to defend itself due to changes in environmental conditions that are unfavorable for bacterial growth [11]. In simple terms, the decomposition process of organic compounds by microorganisms in RBC is explained by chemical reactions [1].

Figure 3 showed a decrease in the total suspended solids in the content of tofu waste that was treated with RBC. The total of TSS content from control and sequence rotation treatments 30,40,50,60 RPM were $(473.50 \mathrm{mg} / \mathrm{L} ; 202.75 \mathrm{mg} / \mathrm{L} ; 169 \mathrm{mg} / \mathrm{L}, 124 \mathrm{mg} / \mathrm{L}$; $82.50 \mathrm{mg} / \mathrm{L}$ respectively). Meanwhile, the efficiency of decreasing TSS levels increases in line with the increase in rotational speed, and the highest level reaches $87.56 \pm 6.48 \%$ at 60 RPM rotation.

Furthermore, Figures 4 and 5 describe the total oxygen demand, both biology, and chemical. Two of the charts have been declining with increasing rotational speed. BOD was $(1480.30 \mathrm{mg} ; 48.94 \mathrm{mg} / \mathrm{L} ; 46.08 \mathrm{mg} / \mathrm{L} ; 20.80 \mathrm{mg} / \mathrm{L}$ and $20.30 \mathrm{mg} / \mathrm{L})$. COD was (9471.84 mg/L; $459.48 \mathrm{mg} / \mathrm{L} ; 452.48 \mathrm{mg} / \mathrm{L} ; 196.92 \mathrm{mg} / \mathrm{L}$ and $169.19 \mathrm{mg} / \mathrm{L})$. The amount of efficiency of reduction BOD and COD extends $99.13 \pm 0.21 \%$ and $98.53 \pm 0.08 \%$ in 60 RPM. COD is bigger more than twice the BOD due to the higher oxygen requirement to degrade organic compounds.

Comparison between results and maximum rate standard that used in Indonesia showed that BOD value in all types of rotation was below the requirements of the permitted waste water quality standard, which is equal to or less than $150 \mathrm{mg} / \mathrm{L}$, contrast with control was beyond the maximum rate. Moreover, control and 30 RPM in TSS results showed exceeding the maximum rate of $200 \mathrm{mg} / \mathrm{L}$, and COD in control $30 \mathrm{RPM}$ and $40 \mathrm{RPM}$ were beyond the maximum rate of $300 \mathrm{mg} / \mathrm{L}$.

Aerobic microbes

Organic matter $+\mathrm{O}_{2} \longrightarrow \mathrm{CO}_{2}+\mathrm{H}_{2} \mathrm{O}+$ new cell + energy for cell + final product 


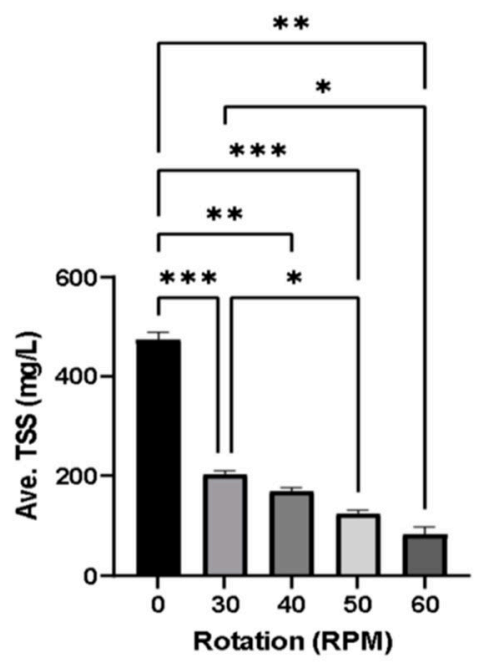

Fig. 3. TSS data shows as mean \pm SEM, different letter superscript means significant different $(\mathrm{p}<0.05)$

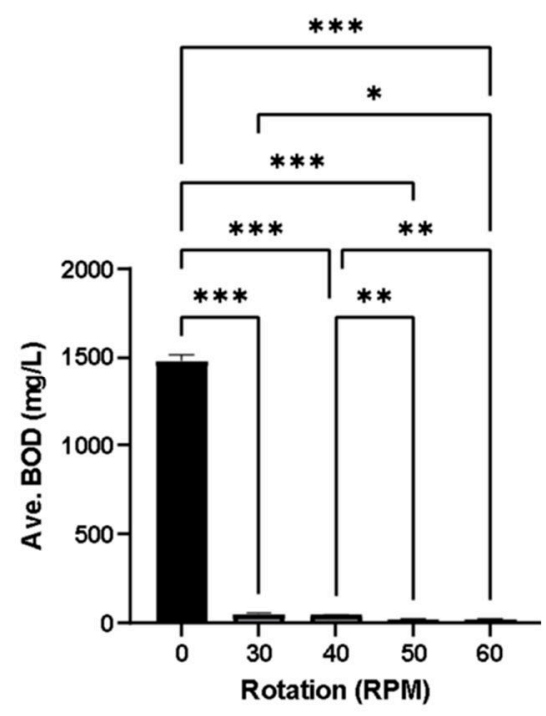

Fig. 4. BOD data shows as mean \pm SEM, different letter superscript means significant different $(\mathrm{p}<0.05)$

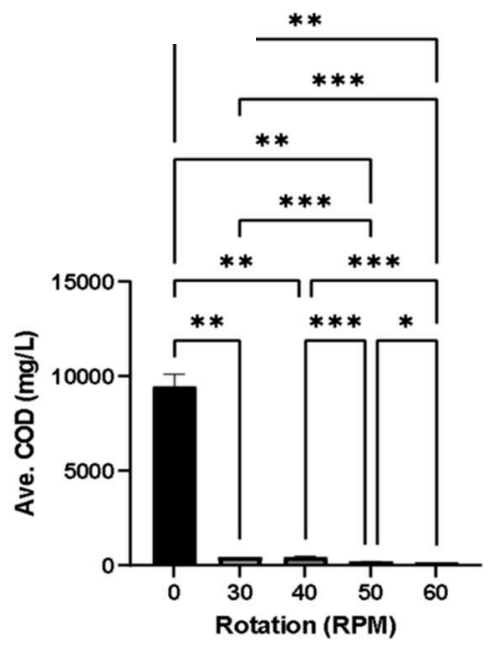

Fig. 5. COD data shows as mean \pm SEM, different letter superscript means significant different $(\mathrm{p}<0.05)$

\section{Discussions}

$\mathrm{RBC}$ media is made from discs that are installed in a row totaling 11 pieces. On each shaft is given spaced $1 \mathrm{~cm}$ every disc. Every reactor tank consists of 2 iron shafts with a total of 22 discs. The space is given between the discs to allow water to enter the disc slit that the biofilm attached to the disc is more effective in degrading organic matter. The RBC media in this study were made of discs covered by carpet. 
The addition of a layer on the disc was functioning as an attachment medium for the biofilm. The surface roughness of the media contributes to the biofilm attachment at the growing stage. Media on RBC has function as a place for growing biomass and restrains solids. According to [14], growing biofilm is easier on a rough surface because it reduces the flow strength that causes biofilm release. The rough surface has a larger surface area.

The efficiency of decreasing TSS, BOD, and COD content is related to an increase in the rotational speed of the RBC medium. A previous study has shown that an increase in the rotational speed of the RBC disk will cause the TSS content in tapioca wastewater to decrease [13]. Therefore, a continuous supply of oxygen in the water and results in aerobic degradation activity. The spin of discs effect increase the dissolved oxygen content in the waste due to the movement of the discs. The oxygen transfer process in RBC has divided into three ways: 1) Oxygen absorption on the top layer of the biofilm surface when the biofilm contacts with the air; 2) Direct oxygen absorption occurs at the air and water interface because of turbulence created by rotating motion and, 3) Direct oxygen absorption by microorganisms [10].

Biofilm will degrade the organic compound in tofu wastewater. The degradation of organic matter occurs when microorganisms utilize organic compounds contained as a food source from complex biochemical reactions, including catabolic and anabolic reactions. In catabolic reactions, food (organic matter) is broken down as energy, and in anabolic reactions, energy is used to synthesize new cells [2].

In addition, figures 4 and 5 showed the decreasing content of BOD and COD. According to Brazil [1], these results report that increasing the rotational speed of the disc can increase organic matter deduction efficiency (BOD) at a given total of organic matter. In the end, decreasing efficiency remains constant even as the rotational speed increases. In contrast to BOD, COD content is usually twice or more than the BOD content. COD is a combination of BOD and other non-biodegradable organic materials. According to [5], if organic matter levels in water are very high, the speed of chemical reactions will be very large. The rate of oxygen consumption will be higher than the rate of oxygen transfer from the air. As a result, dissolved oxygen levels in wastewater will decrease. Therefore, the availability of dissolved oxygen is critical in waste treatment.

\section{Conclusions}

This study has shown that RBC can reduce organic matter with percentage TSS $87.56 \pm$ $6.48 \%$, BOD $99.13 \pm 0.21 \%$, and COD $98.53 \pm 0.08 \%$. To conclude, the optimum rotation is 50 RPM for decreasing BOD and COD, otherwise 40 RPM for reducing TSS. In the rotation 50 and $60 \mathrm{RPM}$, the result has shown below water quality standards according to Table 1.

\section{References}

1. B. L. Brazil, Aquac. Eng 34, 261-274 (2006)

2. H. Effendi, Water Quality Study, for Management of Aquatic Resources and Environment (Kanasius, Yogyakarta, 2003) (In Bahasa Indonesia)

3. A. Herlambang, H.M. Djoko, JAI 4, 146-160 (2008)

4. Irmanto, Suyata, Mol, 4, 105-114 (2009)

5. B. Iswanto, A. Widyo, Sunaryati, Indones. J. Urban Environ. Technol. 4, 24-29 (2007).

6. P. Mathure, P. Ashwin, J. Chem. Technol. Biol. 80, 413-419 (2005). 
7. A. Nurhasan, B.B. Pramudyanto, Tofu Wastewater Treatment (In Bahasa Indonesia) (Yayasan Bina Karta Lestari dan Wahana Lingkungan Hidup Indonesia, Semarang, 1997)

8. R. H. Perry, D.W. Green, Perry's Chemical Engineers' Handbook (McGraw-Hill Book Company, New York, 1997)

9. R. D. Ratnani, I. Hartati, L. Kurniasari, Momentum 7, 41-47 (2011)

10. M. Rodgers, X.-M. Zhan, Rev. Environ. Sci. Biotechnol. 2, 213-224 (2003).

11. I. D. K. Sastrawidana, B.W. Lay, A.M. Fauzi, D.A. Santosa, Ber. Biol. 9, 123-132 (2008)

12. M. Soeparman, Suparmin, Disposal of Feces and Wastewater (In Bahasa Indonesia) (Kedokteran EGC, Jakarta, 2001)

13. F. A. P. Susilo, B. Suharto, L.D. Susanawati, J. Sumberdaya Alam dan Lingkungan 2 , 21-26 (2015)

14. V. G. Waskar, G.S. Kulkarni, V.S. Kore, Int. J. Sci. Res. 2, 7 (2012) 